\title{
Studies in Glycogen Storage Diseases. I. Intestinal Glucose- 6-Phosphatase Activity in Patients with Von Gierke's Disease and Their Parents *
}

\author{
James B. Field, $†$ Sheldon Epstein, $\$$ and Thomas Egan \\ (From the Clinical Research Unit and the Departments of Medicine and Pediatrics, \\ University of Pittsburgh School of Medicine, Pittsburgh, Pa.)
}

Previously we have demonstrated that the enzyme glucose-6-phosphatase is present in normal human small bowel mucosa and suggested that this tissue could be used to establish the diagnosis and study the inheritance of glucose-6-phosphatase deficient glycogen storage disease (Von Gierke's disease) (1). In that study the intestinal glucose-6phosphatase activity of the father of a patient with Von Gierke's disease was found to be clearly decreased, whereas in the mother it was only suggestively diminished. These values were not corrected for nonspecific phosphatase activity, and subsequent results obtained in control subjects indicated that variable amounts of such nonspecific activity were present. The failure to correct for such activity could lead to erroneous conclusions. It was not possible to perform an intestinal biopsy on the patient in this family because of a bleeding tendency. Subsequently Öckerman has reported absent intestinal glucose-6-phosphatase activity in two patients with Von Gierke's disease (2).

The present paper reports very low levels of intestinal glucose-6-phosphatase activity in two patients with proven Von Gierke's disease, as well as definitive results indicating that their parents have significant reductions in the enzyme activity consistent with the heterozygous state and an autosomal recessive inheritance pattern for the disease.

* Submitted for publication October 14, 1964 ; accepted March 24, 1965.

This investigation was supported by U. S. Public Health Service grant AM-08333-01 and General Clinical Research Centers grants FR-56 and FR-84 from the National Institutes of Health. This work was presented in part at the Annual Meeting of the Endocrine Society in San Francisco, Calif., on June 19, 1964.

$\dagger$ Address requests for reprints to Dr. James B. Field, Director, Clinical Research Unit, University of Pittsburgh School of Medicine, Pittsburgh, $\mathrm{Pa}$.

$\ddagger$ Postdoctoral fellow, U. S. Public Health Service.
These studies also emphasize the importance of measuring nonspecific phosphatase in biopsy specimens and correcting the apparent glucose-6-phosphatase activity for this before concluding that a deficiency of glucose-6-phosphatase does not exist. The failure to make this correction can probably explain those cases in the literature that clinically were typical of Von Gierke's disease but had significant amounts of hepatic glucose-6-phosphatase activity (3-5).

\section{Methods}

Clinical material. The case histories of the two patients with Von Gierke's disease are presented in the Appendix. The control subjects were patients with various diseases who were hospitalized at PresbyterianUniversity Hospital or Children's Hospital. Most of them had no evidence of hepatic or gastrointestinal tract disease, but when such was present it is noted in the tables. All subjects were studied in the fasting state.

Experimental methods. Liver tissue was obtained either by biopsy at the time of abdominal surgery or in some instances at autopsy. Small bowel mucosa was obtained from the adults with either a Shiner tube or a Crosby capsule. Specimens were obtained from the small intestine at the area of the ligament of Treitz - under fluoroscopic control. Intestinal mucosa from the two patients with Von Gierke's disease and the three control children was obtained from the same area at the time of abdominal surgery. Biopsies of rectal mucosa were done with an anoscope. Guinea pig intestinal mucosa was removed from the first 2 to 3 inches of the small bowel by blunt dissection.

Intestinal glucose-6-phosphatase activity was measured during a 45-minute incubation as previously described (1). Specimens of intestinal mucosa weighing between 8 and $45 \mathrm{mg}$ were homogenized in from 1 to $2.5 \mathrm{ml}$ of glass distilled water. One-tenth-ml samples of the homogenate were added to the incubation medium, which consisted of $0.3 \mathrm{ml}$ of $0.1 \mathrm{M}$ maleic acid buffer $\mathrm{pH} 6.5$ and $0.1 \mathrm{ml}$ of either $0.1 \mathrm{M}$ glucose-6-phosphate or $0.1 \mathrm{M}$ $\beta$-glycerol phosphate (containing less than $0.1 \% \quad \alpha$-isomer). The latter substrate was used to correct for nonspecific phosphatase activity. The reaction was termi- 
nated by adding $1 \mathrm{ml}$ of $10 \%$ trichloroacetic acid and chilling the tubes in ice for 5 minutes. Inorganic phosphate phosphorus was determined in $1-\mathrm{ml}$ samples of the supernatant by the method of Fiske and SubbaRow. Homogenate and substrate blanks were included with each incubation and the results expressed as inorganic phosphate phosphorus liberated per gram of tissue protein. With this procedure it has been demonstrated that the $\mathrm{pH}$ optimum of true glucose-6-phosphatase is 6.5 and that the reaction was linear with time and proportional to the amount of tissue assayed (1). Phosphate liberation from glycerol phosphate also was linear with time and was greater at $\mathrm{pH} 5$ and 7.5 than at $\mathrm{pH} 6.5$.

Hepatic glucose-6-phosphatase was assayed in exactly the same manner except that $0.1 \mathrm{ml}$ of liver homogenate was used and the incubation time was reduced to $15 \mathrm{~min}$ utes. The liver homogenate contained 35 to $136 \mathrm{mg}$ of tissue per $\mathrm{ml}$ of glass distilled water. The more concentrated homogenates were used when glucose-6-phosphatase activity was expected to be low. The data in Figure 1 indicate that the $\mathrm{pH}$ optimum of hepatic glucose-6-phosphatase is between pH 6.5 and 7.0, similar to that of the enzyme obtained from rat liver (6). At this $\mathrm{pH}$ the ac-

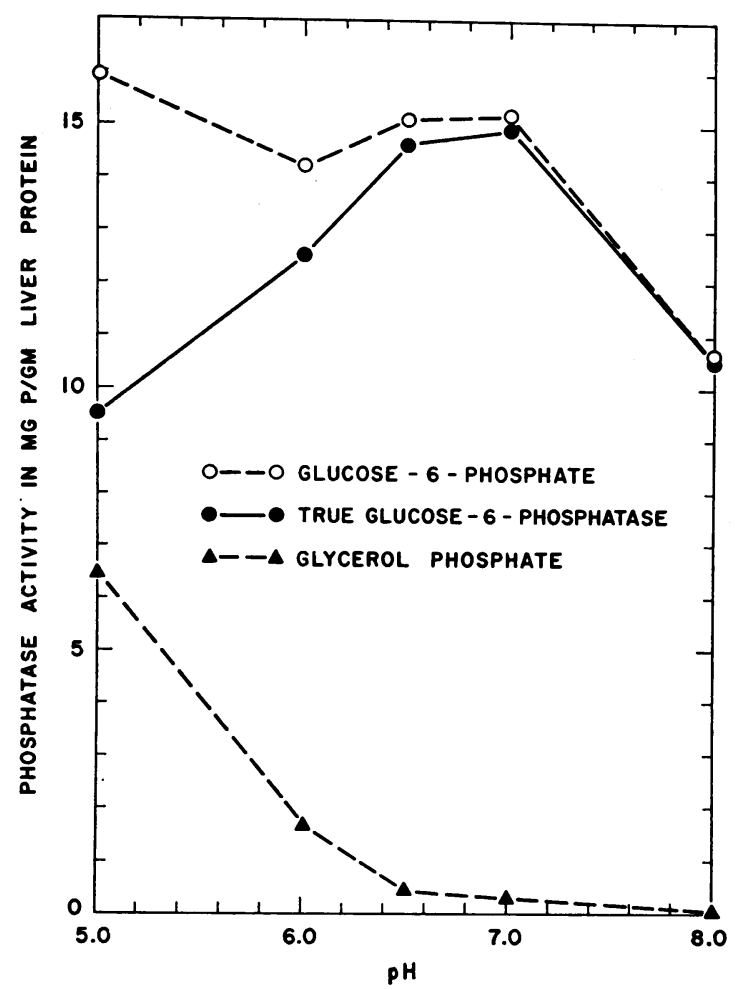

Fig. 1. Effect of PH on hepatic glucose-6-PhosPHAtase ACtrvity. True glucose-6-phosphatase activity is obtained by subtracting the activity with glycerol phosphate as substrate from that obtained with glucose-6-phosphate as substrate. Acetate buffer $(0.1 \mathrm{M})$ was used for the assay at $\mathrm{pH} 5$, and $0.1 \mathrm{M}$ Tris-maleate buffer was used for all the other points.

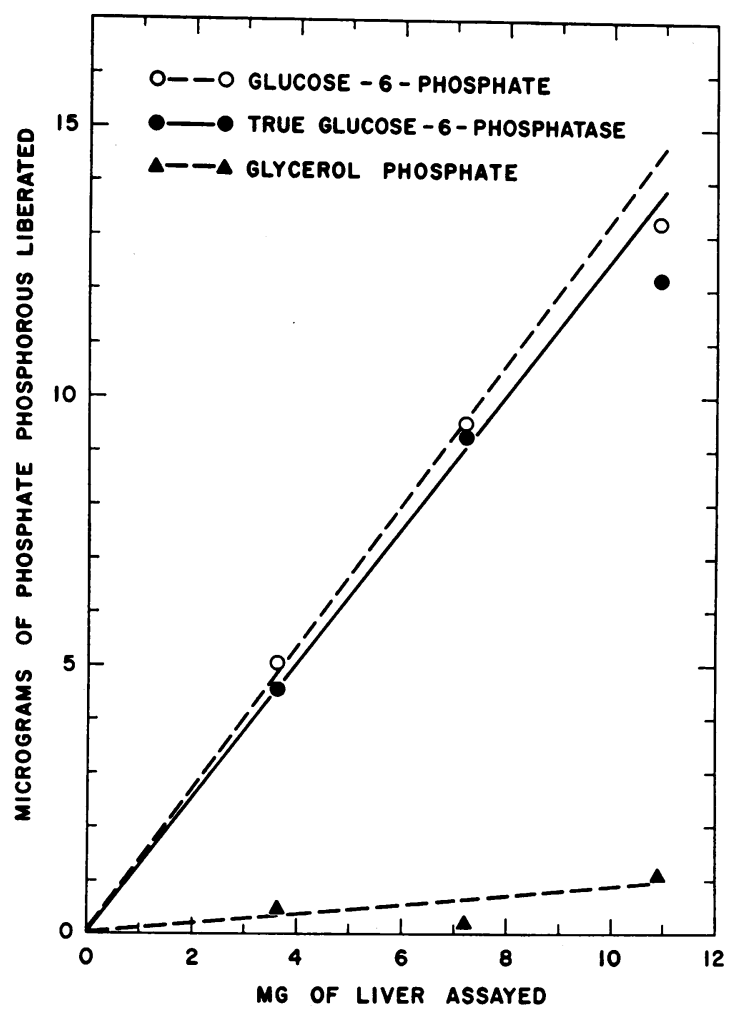

Fig. 2. Relationship Between hepatic GLucose-6PHOSPHATASE ACTIVITY AND AMOUNT OF TISSUE ASSAYED.

tivity using glycerol phosphate as substrate was usually very low but was consistently greater at $\mathrm{pH}$ 5.0. The absence of nonspecific phosphatase in hepatic homogenates at $\mathrm{pH} 7.5$ to 8.0 is in marked contrast to the findings with intestinal homogenate where phosphate liberation from glycerol phosphate was greater at this $\mathrm{pH}$ than at a lower $\mathrm{pH}$. Swanson has suggested that the activity at $\mathrm{pH} 5.0$ and 7.5 to 8.0 is not due to the group of enzymes usually known as acid or alkaline phosphatases, since $\mathrm{Mg}^{++}$, which is thought to be necessary for activation of these enzymes, was not added to the incubation medium (6). Although hepatic glucose-6-phosphatase activity is reported not to be proportional with dilution (6), the data in Figure 2 indicate that over the range of hepatic tissue usually assayed there was proportionality with both glucose-6-phosphate and glycerol phosphate as substrates. Figure 3 indicates that the enzyme activity was linear with time. The in vitro effect of glucose on intestinal and hepatic glucose-6-phosphatase activity was studied by adding $0.1 \mathrm{ml}$ of a $1 \mathrm{M}$ solution to the incubation mixture. This procedure was done with both glucose-6-phosphate and glycerol phosphate as substrate.

Hepatic phosphorylase was assayed by the method of Sutherland (7). In some experiments homogenate was incubated for both 20 and 30 minutes to determine the linearity of the reaction. The concentration of the ho- 


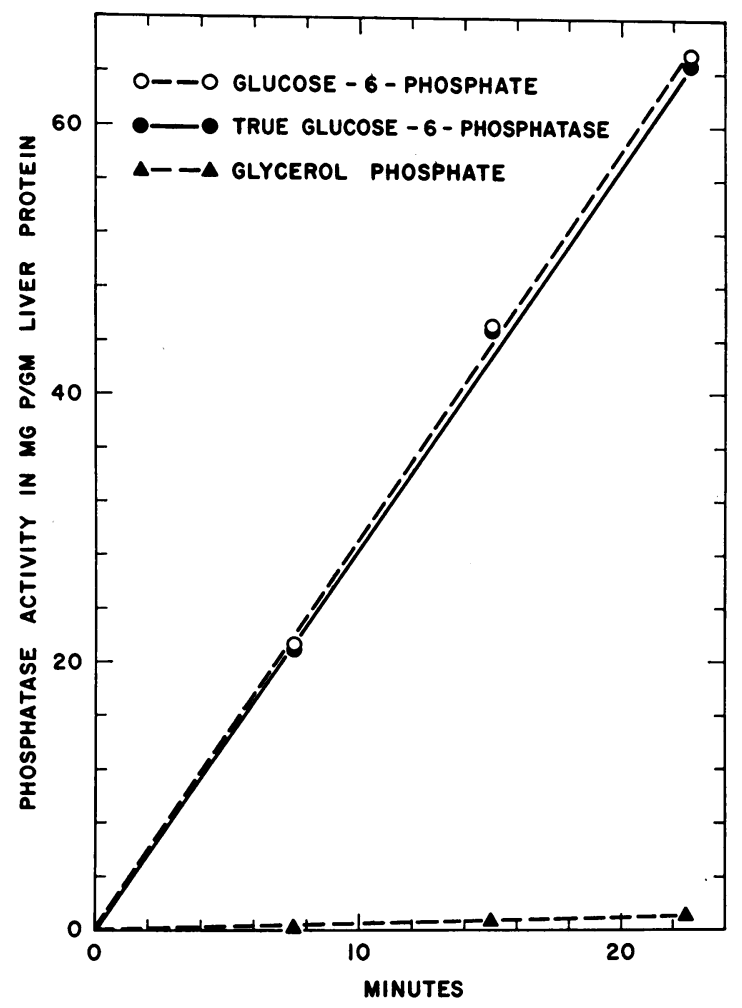

Fig. 3. Hepatic glucose-6-Phosphatase activity as a FUNCTION OF TIME.

mogenate varied between 34 and $150 \mathrm{mg}$ per $\mathrm{ml}$ of $0.1 \mathrm{M}$ $\mathrm{NaF}$. Debranching enzyme in liver tissue was measured by the procedure of Hers (8) using $0.1 \mathrm{ml}$ and $0.2 \mathrm{ml}$ of a homogenate containing between 35 and $135 \mathrm{mg}$ of tissue per $\mathrm{ml}$ of glass distilled water. The incubation time was 45 minutes, and $1.3 \mu \mathrm{c}$ glucose- $1-\mathrm{C}^{14}(1,300,000 \mathrm{cpm}, \mathrm{SA}$ $3.88 \mathrm{mc}$ per mmole) was present in each tube. The results of these various hepatic enzyme studies on the two patients with Von Gierke's disease and the control subjects are tabulated in Table I.

Leukocyte phosphorylase (9) and debranching enzyme (10) were assayed as previously described. The intestinal and hepatic glycogen content were measured by the method of Carroll, Longley, and Roe (11). Protein was determined by the method of Lowry, Rosebrough, Farr, and Randall (12).

\section{Results}

The data in Table II indicate that the two patients with Von Gierke's disease had very little true glucose-6-phosphatase activity in small bowel mucosa. Although intestinal homogenate obtained from S.T. liberated $16.9 \mathrm{mg}$ phosphorus per $\mathrm{g}$ protein when glucose-6-phosphate was used as substrate, an almost equivalent amount of $\mathrm{P}$ was liberated from $\beta$-glycerol phosphate, indicating that most of this activity represented nonspecific phosphatases rather than true glucose-6-phosphatase. The average true glucose-6-phosphatase activity in the three control children was $18.5 \mathrm{mg} P$ per $g$ protein, and there was a variable amount of nonspecific phosphatase.

The intestinal glucose-6-phosphatase activity of control adults averaged $46.4 \mathrm{mg} P$ per $\mathrm{g}$ protein and was considerably greater than that found in children. In our previous report (1), glucose-6-

TABLE I

Hepatic glucose-6-phosphatase, phosphorylase, and debranching enzyme in control subjects and patients with Von Gierke's disease

\begin{tabular}{|c|c|c|c|c|c|c|c|c|c|}
\hline \multicolumn{3}{|c|}{ Subjects } & \multicolumn{3}{|c|}{ Phosphatase activity } & \multirow{2}{*}{\multicolumn{2}{|c|}{$\begin{array}{c}\text { Phosphorylase activity } \\
\text { Incubation time }\end{array}$}} & \multirow{2}{*}{\multicolumn{2}{|c|}{$\begin{array}{l}\text { Debranching enzyme activity } \\
\text { Amount of liver homogenate }\end{array}$}} \\
\hline & \multirow[b]{2}{*}{ Sex } & \multirow{2}{*}{$\begin{array}{c}\text { Tissue } \\
\text { obtained } \\
\text { by }\end{array}$} & \multirow[b]{2}{*}{ Total } & \multirow{2}{*}{$\begin{array}{l}\text { Non- } \\
\text { specific }\end{array}$} & \multirow{2}{*}{$\begin{array}{c}\text { True } \\
\text { glucose-6- } \\
\text { phosphatase }\end{array}$} & & & & \\
\hline Age & & & & & & $20 \mathrm{~min}$ & $30 \mathrm{~min}$ & $0.1 \mathrm{ml}$ & $0.2 \mathrm{ml}$ \\
\hline \multirow{2}{*}{\multicolumn{3}{|c|}{ 1. Control subjects }} & \multirow{2}{*}{\multicolumn{3}{|c|}{$m g P / g$ protein }} & \multirow{2}{*}{\multicolumn{2}{|c|}{$m g P / g$ protein }} & \multirow{2}{*}{\multicolumn{2}{|c|}{$c p m / g$ protein }} \\
\hline & & & & & & & & & \\
\hline $1 \frac{1}{2}$ & $\mathbf{M}$ & Biopsy & 64.4 & 9.6 & 54.8 & 108 & & 866,000 & 876,000 \\
\hline $1 \frac{1}{2}$ & $\mathbf{M}$ & Biopsy & 37.9 & $\mathbf{0}$ & 37.9 & & & 604,000 & \\
\hline $3 \frac{1}{2}$ & $\mathrm{~F}^{*}$ & Biopsy & 21.6 & $\mathbf{0}$ & 21.6 & 60.8 & 78.2 & & \\
\hline 2 & $\mathbf{M} \dagger$ & Biopsy & 35.7 & 1.2 & 34.5 & 38.6 & 50.5 & 690,000 & 745,000 \\
\hline 29 & $\mathbf{F}$ & Biopsy & 29.2 & 15.4 & 13.8 & 80.6 & 116 & $1,280,000$ & $1,050,000$ \\
\hline 39 & $\mathbf{F}$ & Biopsy & 14.5 & 0 & 14.5 & & & $1,310,000$ & \\
\hline 60 & $\mathbf{M}$ & Autopsy & 20.2 & $\mathbf{0}$ & 20.2 & & & & \\
\hline 65 & $\mathbf{M}$ & Autopsy & 16.3 & $\mathbf{0}$ & 16.3 & $\mathbf{0}$ & 0 & 560,000 & 500,000 \\
\hline \multicolumn{3}{|c|}{ Mean \pm SEM } & $30.0 \pm 5.8$ & $3.3 \pm 2.1$ & $26.7 \pm 5.1$ & $72 \pm 14.7$ & $81.6 \pm 18.9$ & $885,000 \pm 136,579$ & $792,750 \pm 365,245$ \\
\hline \multicolumn{10}{|c|}{ 2. Von Gierke's patients } \\
\hline $1 \frac{1}{2}$ S.T. & $\mathbf{F}$ & Biopsy & 10.1 & 11.2 & 0 & 114.5 & 164.2 & $1,360,000$ & $1,210,000$ \\
\hline 4 D.R. & $\mathbf{F}$ & Biopsy & 19.8 & 20.1 & 0 & 121 & 155 & 710,000 & 860,000 \\
\hline
\end{tabular}

* This patient was found to have biliary atresia at surgery.

* This patient was found to have biliary atresia at surgery.
$t$ This patient was found to have cirrhosis of the liver at surgery. Clinically he is suspected of having Type IV glycogen storage disease. 
phosphatase activity was expressed in terms of milligrams $\mathrm{P}$ per gram wet weight, and the average activity in six control subjects was 4.65 . In the present studies more consistent results were obtained if the activity was expressed in terms of weight of protein rather than wet weight. Usually $10 \mathrm{mg}$ of wet weight of intestine was equivalent to approximately $1 \mathrm{mg}$ of protein (unpublished data) so that the results obtained with these two groups of control subjects are in close agreement. The father and mother of patient S.T. had values of 26.3 and $28.8 \mathrm{mg} \mathrm{P}$ per $\mathrm{g}$ protein, respectively, whereas the father and mother of D.R. had activities of 21.4 and $22 \mathrm{mg} P$ per $g$ protein, respectively. All of these values are clearly below the range obtained with intestinal mucosa from the control adult subjects. One of the control subjects (46 F) was the mother of a patient with Type III glycogen storage disease (debranching enzyme deficiency), and her intestinal mucosa had an activity of $47.3 \mathrm{mg} P$ per $\mathrm{g}$ protein.

Von Gierke's disease is characterized by increases in the glycogen content of liver and kid-

TABLE II

Intestinal glucose-6-phosphatase activity in control subjects, patients with Von Gierke's disease, and their parents

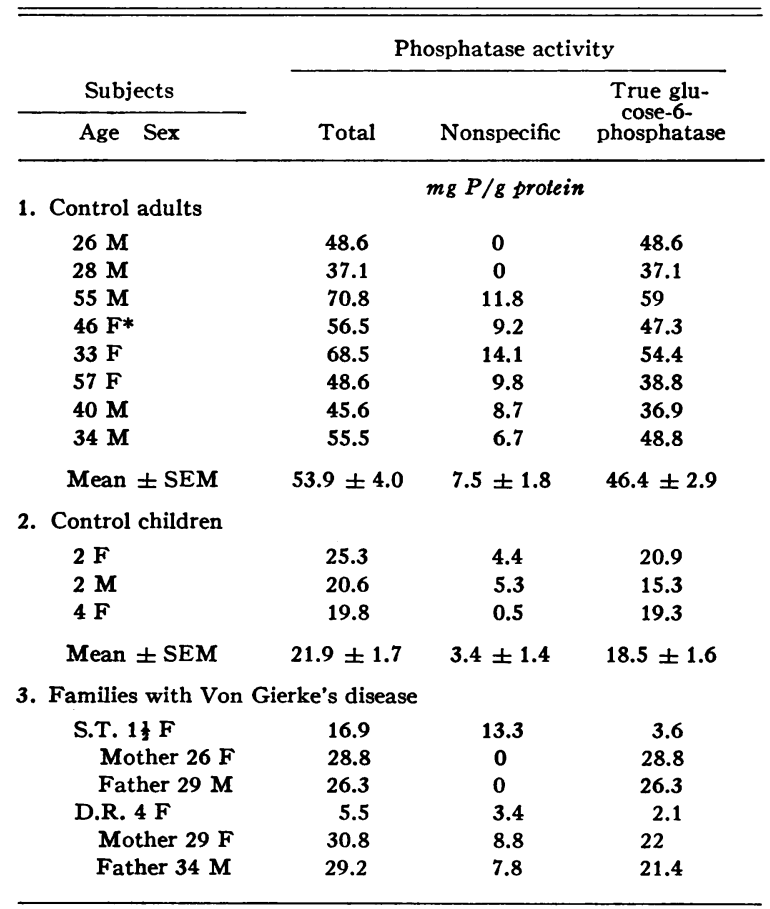

* Mother of a patient with Type III glycogen storage disease (debranching enzyme deficiency).
TABLE III

Intestinal glycogen concentration in control subjects, patients with Von Gierke's disease, and their parents

\begin{tabular}{|c|c|c|}
\hline \multicolumn{2}{|r|}{ Subjects } & \multirow{2}{*}{$\begin{array}{l}\% \text { glycogen con- } \\
\text { tent based on } \\
\text { wet wt of tissue }\end{array}$} \\
\hline Age & Sex & \\
\hline \multicolumn{3}{|c|}{ 1. Control adults } \\
\hline $\begin{array}{l}50 \\
55 \\
46 \\
34\end{array}$ & $\begin{array}{l}\mathrm{M} \\
\mathrm{M} \\
\mathrm{F} \\
\mathbf{M}\end{array}$ & $\begin{array}{l}0.11 \\
0.08 \\
0.06 \\
0.07\end{array}$ \\
\hline \multicolumn{2}{|c|}{ Mean \pm SEM } & $0.08 \pm 0.008$ \\
\hline \multicolumn{3}{|c|}{ 2. Control children } \\
\hline $\begin{array}{l}1 \frac{1}{2} \\
4\end{array}$ & $\begin{array}{l}\mathrm{M} \\
\mathrm{F}\end{array}$ & $\begin{array}{l}0.13 \\
0.12 \\
0.07\end{array}$ \\
\hline \multicolumn{2}{|c|}{ Mean \pm SEM } & $0.11 \pm 0.013$ \\
\hline \multicolumn{3}{|c|}{ 3. Families with Von Gierke's disease } \\
\hline $\begin{array}{r}\text { S.T. } \\
\mathrm{M} \\
\mathrm{Fa} \\
\text { D.R } \\
\mathrm{M} \\
\mathrm{Fa}\end{array}$ & $\begin{array}{l}1 \frac{1}{2} \mathrm{~F} \\
\text { Mother } 26 \mathrm{~F} \\
\text { ather } 29 \mathrm{M} \\
\text { R. } 4 \mathrm{~F} \\
\text { Mother } 29 \mathrm{~F} \\
\text { ather } 34 \mathrm{M}\end{array}$ & $\begin{array}{l}0.54 \\
0.06 \\
0.11 \\
0.23 \\
0.06 \\
0.00\end{array}$ \\
\hline
\end{tabular}

neys as well as deficiencies of glucose-6-phosphatase in these tissues. Normally the glycogen content of intestinal mucosa is quite low, but elevated levels were detected in both patients with Type I glycogen storage disease (Table III). Although it was possible to detect the heterozygous state in the parents of these two patients as manifested by significant reduction of intestinal glucose-6-phosphatase activity, this was not true when intestinal glycogen content was measured.

In view of the marked difference between the intestinal glucose-6-phosphatase activity in children as compared to adults, studies were done using guinea pigs of different ages (Table IV). The intestinal glucose-6-phosphatase activity was sig-

TABLE IV

Comparison of intestinal and hepatic glucose-6-phosphatase in young and adult guinea pigs

\begin{tabular}{ccc}
\hline \multirow{2}{*}{ Age } & \multicolumn{2}{c}{ True glucose-6-phosphatase activity } \\
\cline { 2 - 3 } & \multicolumn{3}{c}{ Intestinal } & Hepatic \\
\hline 3 weeks & $25.4 \pm 3.5(9)^{*}$ & $44.2 \pm 3.3(5)$ \\
8 weeks & $51.2 \pm 6.8(5)$ & $42.9 \pm 1.3(5)$ \\
12 weeks & $45.4 \pm 7.7(5)$ & $39.8 \pm 2.1(5)$ \\
18 weeks & $44.6 \pm 4.9(5)$ & $49.9 \pm 2.0(5)$
\end{tabular}

* No. of animals in parentheses. 
TABLE $V$

Glucose inhibition of glucose-6-phosphatase activity

\begin{tabular}{|c|c|c|c|c|}
\hline \multirow[b]{2}{*}{ Tissue } & \multicolumn{4}{|c|}{\begin{tabular}{cc}
\multicolumn{2}{c}{ P liberated from } \\
Glucose-6- & $\beta$-Glycerol \\
phosphate & phosphate \\
Glucose & Glucose
\end{tabular}} \\
\hline & - & + & - & + \\
\hline & \multicolumn{4}{|c|}{$m g P / g$ protein } \\
\hline Human intestine & 53.3 & 27.9 & 6.4 & 7.4 \\
\hline Human intestine & 63.6 & 20.9 & 6.8 & 8.3 \\
\hline Human intestine & 55.5 & & 6.7 & 6.7 \\
\hline Guinea pig intestine & 51.1 & 18.1 & 11.1 & 11.3 \\
\hline Guinea pig intestine & 51.2 & 21.7 & 8.8 & 10.1 \\
\hline Human liver & 18.6 & 9.3 & 1.6 & 1.9 \\
\hline Guinea pig liver & 39.9 & 19.2 & 1.6 & 2.1 \\
\hline Guinea pig liver & 44.2 & 23.7 & 1.4 & 1.5 \\
\hline
\end{tabular}

nificantly lower in the 3-week-old guinea pigs as compared to the older animals. In contrast hepatic glucose-6-phosphatase activity did not vary with age.

Glucose has been reported to inhibit hepatic glucose-6-phosphatase activity but not nonspecific phosphatase (13). While the present work was in progress, Lea and Walker reported the same observation using intestinal mucosa obtained from the guinea pig (14). The data in Table V demonstrate that human intestinal glucose-6-phosphatase is also inhibited by glucose, whereas nonspecific phosphatase assayed under identical conditions was unaffected. Glucose-6-phosphatase activity has been reported to be present in rectal mucosa by a histochemical technique (15), but no such activity was found in rectal mucosa obtained from two control subjects. Although a small amount of $P$ was liberated from glucose-6-phosphate by homogenates of rectal mucosa, an equivalent amount was also obtained with $\beta$-glycerol phosphate.

\section{Discussion}

The present studies confirm and extend our suggestion that intestinal mucosa can be used for the diagnosis and genetic study of Von Gierke's disease (1). Originally the parents and sibling of a patient with Von Gierke's disease were studied, but intestinal biopsy was not done on the patient himself because of a bleeding tendency. Glucose6-phosphatase activity of the intestinal mucosa obtained from the father was clearly decreased, but the mother's intestinal enzyme activity was only slightly lower than some of the normals included in that report (1). At the time the studies were done on this family, glucose-6-phosphate was the only substrate used, and no correction was made for nonspecific phosphatase activity, which may have been appreciable. In all six control subjects in the original report (1) and in nine of eleven controls in the present study, a variable but significant amount of the total phosphatase activity was accounted for by nonspecific phosphatases. It would thus not be unreasonable to suspect that the value obtained with intestinal mucosa from the mother actually was also decreased and that both parents were heterozygotes. The present findings of significantly decreased intestinal true glucose-6phosphatase activity in both parents of two more cases of Type I glycogen storage disease support a recessive type of inheritance for this disease. The values obtained in the heterozygotes are approximately $50 \%$ of normal.

The demonstration that Von Gierke's disease is transmitted as an autosomal recessive indicates that the inheritance of the various types of glycogen storage diseases may be different. Evidence has been presented that hepatic phosphorylase deficient glycogen storage disease is inherited as a dominant with incomplete penetrance $(9,16)$. In one family with a child suffering from debranching enzyme deficiency type glycogen storage disease, the type of inheritance appeared to be that of an autosomal recessive (10).

The marked decrease of intestinal true glucose6-phosphatase in two patients with Von Gierke's disease confirms the observation of Öckerman, who was unable to detect any activity in two patients (2). His report did not include any data on other family members. It would now seem sufficiently well established that the intestinal enzyme activity is an authentic indication of the hepatic enzyme activity and can be used to confirm the diagnosis without the necessity and risk of liver biopsy. The similarity between hepatic and intestinal glucose-6-phosphatase is further suggested by the fact that the latter enzyme is also inhibited by the addition of glucose (Table V). The kinetics of the glucose inhibition of glucose-6-phosphatase have been studied in detail by Hass and Byrne (13). The ability of glucose to similarly inhibit guinea pig intestinal glucose-6-phosphatase was recently reported by Lea and Walker, who also presented kinetic data supporting the con- 
tention that the hepatic and intestinal enzyme activities were the same (14).

The marked difference in the intestinal glucose6-phosphatase activity between children and adults was not expected. However, a similar reduction in glucose-6-phosphatase was found in the intestinal mucosa of 3-week-old guinea pigs (Table IV). Our results in guinea pigs differ from those of Lea and Walker, who found identical amounts of the intestinal enzyme in young and adult guinea pigs (14). The reason for this discrepancy is not clear at the present time, although it may be pertinent that all of their young animals were less than 10 days old and their adult animals were 4 months old.

Patients with Von Gierke's disease have elevated hepatic and renal glycogen content associated with the deficiency of glucose-6-phosphatase. The data in Table III indicate that this relationship also applies to the intestinal mucosa. However, these findings are at variance with those of Öckerman, who reported normal intestinal glycogen values in his two cases (2). Examination of his data indicates that although there was some overlap between his patients and the controls, one patient had an intestinal glycogen content higher than all of the controls, and the other had a level that was exceeded only by one of the five control values. The values that Öckerman reported are considerably higher than those we have obtained. The parents of our two patients had intestinal glycogen contents that were indistinguishable from the controls, indicating that this parameter does not segregate the heterozygote, whereas assays for intestinal glucose-6-phosphatase will make this distinction.

The etiologic role of deficiency of glucose-6phosphatase in Von Gierke's disease has been clouded by the occasional reports in the literature of patients with the typical clinical features of this disease but whose livers contained normal amounts or only moderate reduction in amount of this enzyme (3-5). An explanation for this apparent discrepancy is suggested by the observation that liver homogenates obtained from patients D.R. and S.T. liberated normal and almost normal amounts of $\mathrm{P}$ from glucose-6-phosphate. However, equivalent amounts of $\mathrm{P}$ were also obtained using $\beta$-glycerol phosphate as substrate (Table I). These findings indicated that the activity was due to nonspecific phosphatases rather than true glu- cose-6-phosphatase. Had this correction for nonspecific phosphatase not been included in the experimental design, D.R. and S.T. would have been diagnosed as cases of Von Gierke's disease clinically but with normal or near normal amounts of hepatic glucose-6-phosphatase. Similar conclusions might have been drawn from the intestinal enzyme studies in S.T., since a near normal amount of $\mathrm{P}$ was released from glucose-6-phosphate, but almost all of this was the result of nonspecific phosphatase (Table II). In those cases in the literature where no or only slight reduction of glucose-6-phosphatase activity was found, no mention is made of correction for nonspecific phosphatases (3-5). The presence of such enzymes would satisfactorily explain the apparent glucose-6-phosphatase activity reported. Although the $\mathrm{pH}$ optimum of glucose-6-phosphatase is 6.5 and quite different from that of acid and alkaline phosphatases, it is apparent that even at this $\mathrm{pH}$ there can be considerable activity attributable to other phosphatases. The nonspecific phosphatase activity also appears to be linear with time and have a $\mathrm{pH}$ optimum more acid than 6.5 (Figures 1 and 3 ). Although both S.T. and D.R. had considerable nonspecific phosphatase activity in their liver homogenate, the data are insufficient to conclude that this represents a significant increase over the controls.

\section{Summary}

Intestinal glucose-6-phosphatase activity was markedly deficient in two cases of Von Gierke's disease. Both parents of each patient had significantly decreased intestinal glucose-6-phosphatase activities consistent with the heterozygous state and a recessive type of inheritance for this disease. Although the intestinal glycogen content was increased in the two patients, the levels found in their parents were indistinguishable from the control subjects. Intestinal glucose-6-phosphatase activity was inhibited by glucose, which had no effect on nonspecific phosphatase. The intestinal glucose-6-phosphatase was significantly lower in control children as compared to control adults, and similar findings were noted in 3-week-old guinea pigs. Both of the patients with Von Gierke's disease had high levels of hepatic nonspecific phosphatase activity but no true glucose-6phosphatase when the assays were corrected for 
activity obtained with $\beta$-glycerol phosphate as substrate. This observation probably explains those clinical cases of Von Gierke's disease who did not have reductions in hepatic glucose-6-phosphatase activity since no corrections had been made for nonspecific phosphatases.

\section{Appendix}

Case I: D.R. This 4-year-old white female child was the product of a normal pregnancy and weighed 6 pounds, 6 ounces at birth. Although the patient doubled her birth weight during the first 6 months, her mother felt that frequent feedings were necessary. Many attacks of rapid breathing were noted especially in the morning, but they appeared to be relieved by eating. Hepatomegaly was first found at age 6 months. Fasting blood glucose on two different occasions was $8.5 \mathrm{mg}$ per $100 \mathrm{ml}$ and $5 \mathrm{mg}$ per $100 \mathrm{ml}$, and epinephrine administration produced no significant rise. The serum cholesterol was $286 \mathrm{mg}$ per $100 \mathrm{ml}$, and the total lipids were $5,833 \mathrm{mg}$ per $100 \mathrm{ml}$. The alkaline phosphatase was 2.8 Bodansky $\mathrm{U}$, and the thymol turbidity was $12.6 \mathrm{U}$. A liver biopsy was interpreted as being consistent with a diagnosis of glycogen storage disease. No enzyme studies were performed, and the hepatic glycogen concentration was not determined.

On a regimen of frequent feedings she did moderately well but was hospitalized several times during the next 2 years because of acidosis usually associated with minor infections. Lesions of xanthoma tuberosum disseminata appeared on her extremities and trunk. Except for epistaxis about once every 2 months, there was no other evidence of a bleeding tendency.

The patient's mother was 27 years old and her father 30 years old. There was no history of consanguinity. Two siblings were normal.

On admission to the Clinical Research Unit of Presbyterian-University Hospital, the positive physical findings were as follows. The patient was poorly developed with a protuberant abdomen. She weighed 25 pounds and was 33 inches tall. Lipemia retinalis was present. There were dilated superficial veins over the abdomen. The liver edge was sharp, nontender, and extended to the iliac crest. There were scattered $2-$ to $3-\mathrm{mm}$ yellowish nodules especially over the elbows and knees. Laboratory studies revealed a normal urinalysis except for acetonuria. The hemoglobin was $10.6 \mathrm{~g}$, and the leukocyte count was 6,700 per $\mathrm{mm}^{3}$ with a differential of $21 \%$ polymorphonuclear cells, $65 \%$ lymphocytes, $5 \%$ eosinophils, $8 \%$ monocytes, and $1 \%$ basophils. Fasting blood sugars varied from $5 \mathrm{mg}$ per $100 \mathrm{ml}$ to $40 \mathrm{mg}$ per $100 \mathrm{ml}$. The serum sodium was $130 \mathrm{mEq}$ per $\mathrm{L}$, potassium $3.9 \mathrm{mEq}$ per $\mathrm{L}$, chloride $84 \mathrm{mEq}$ per $\mathrm{L}$, and the carbon dioxide content $9.1 \mathrm{mEq}$ per $\mathrm{L}$. The serum uric acid was $6.0 \mathrm{mg}$ per $100 \mathrm{ml}$. The cholesterol was $535 \mathrm{mg}$ per $100 \mathrm{ml}$, phospholipid $1,213 \mathrm{mg}$ per $100 \mathrm{ml}$, and the triglycerides $6,414 \mathrm{mg}$ per $100 \mathrm{ml}$. The total protein as measured by the biuret method was reported to be $17.7 \mathrm{~g}$ with $10 \mathrm{~g}$ of albumin and $7.7 \mathrm{~g}$ of globulin of which $1.6 \mathrm{~g}$ was $\gamma$-globulin. Since these values were unusually high, it was originally thought that the hyperlipemia was causing spurious elevations. However, a similar value was obtained when the determination was done using a refractometer. Serum water was $81.7 \mathrm{~g}$ per $100 \mathrm{ml}$ of serum, and the solids were $18.3 \mathrm{~g}$. Even if $8 \mathrm{~g}$ of this represents lipid, the serum proteins would be high. Ether extraction of the serum was done to remove lipids before measuring the serum proteins. The unextracted serum contained $15.5 \mathrm{~g}$ per $100 \mathrm{ml}$ protein, whereas after ether extraction, the serum had $8.6 \mathrm{~g}$ per $100 \mathrm{ml}$. The ether extract contained $7.6 \mathrm{~g}$ per $100 \mathrm{ml}$ protein. The explanation for these high protein values is not apparent. An oral glucose tolerance test gave the following results : fasting, $8 \mathrm{mg}$ per $100 \mathrm{ml}$; $\frac{1}{2}$ hour, $117 \mathrm{mg}$ per $100 \mathrm{ml} ; 1$ hour, $129 \mathrm{mg}$ per $100 \mathrm{ml} ; 2$ hours, $127 \mathrm{mg}$ per $100 \mathrm{ml} ; 3$ hours, $85 \mathrm{mg}$ per $100 \mathrm{ml}$; 4 hours, $21 \mathrm{mg}$ per $100 \mathrm{ml}$; and 5 hours, $5 \mathrm{mg}$ per $100 \mathrm{ml}$. Despite the hypoglycemia at the beginning and end of the test, she did not complain of any symptoms. The response of her blood glucose to injection of $1 \mathrm{mg}$ of glucagon im was as follows: fasting, $15 \mathrm{mg}$ per $100 \mathrm{ml} ; 15$ minutes after glucagon, $10 \mathrm{mg}$ per $100 \mathrm{ml} ; 30$ minutes, $10 \mathrm{mg}$ per $100 \mathrm{ml}$; 60 minutes, $9 \mathrm{mg}$ per $100 \mathrm{ml}$. Leukocyte phosphorylase and debranching enzyme activities were normal. The bleeding and clotting times were normal. Biopsies of the liver and the intestinal mucosa were obtained at surgery. Histologically the liver contained increased glycogen and an abnormal accumulation of lipid and was consistent with a diagnosis of glycogen storage disease.

True hepatic glucose-6-phosphatase could not be detected, but normal amounts of hepatic phosphorylase and debranching enzyme were assayed (Table I). The glycogen content of the liver was $8.4 \mathrm{~g}$ per $100 \mathrm{ml}$ based on wet weight of the tissue. The intestinal mucosa was normal histologically.

Case II: S.T. The patient was a product of a normal full-term pregnancy. Her birth weight was 6 pounds, 10 ounces. At 3 months of age she was noted to have jerky spells lasting about 5 minutes without loss of consciousness. At age 6 months she was hospitalized because of pneumonia, and hepatomegaly was first noted. A liver biopsy was reported to be histologically consistent with glycogen storage disease, although no enzyme or chemical studies were done.

The patient's mother was 23 and her father 25 . There was no history of consanguinity. Two siblings were living and well.

On admission to the hospital she was a thin, ill-nourished, highly irritable child with a protuberant abdomen. She weighed 14.5 pounds and was 29 inches long. The liver edge was palpable 5 finger breadths below the costal margin. The extremities were weak with poor muscle tone.

The hemoglobin was $11.4 \mathrm{~g}$, and the hematocrit was $35 \%$. The leukocyte count was 6,500 cells per $\mathrm{mm}^{3}$ with $35 \%$ polymorphonuclear cells, $4 \%$ metamyelocytes, $57 \%$ lymphocytes, and $4 \%$ eosinophils. Urinalysis revealed a trace of acetone but no other abnormalities. Fasting blood glucose ranged from $8 \mathrm{mg}$ per $100 \mathrm{ml}$ to $97 \mathrm{mg}$ per 
$100 \mathrm{ml}$. The carbon dioxide content was $12 \mathrm{mEq}$ per $\mathrm{L}$, sodium $133 \mathrm{mEq}$ per L, chloride $99 \mathrm{mEq}$ per L, and potassium $4.2 \mathrm{mEq}$ per L. The uric acid was $11.7 \mathrm{mg}$ per 100 $\mathrm{ml}$, and the cholesterol was $198 \mathrm{mg}$ per $100 \mathrm{ml}$, phospholipids $360 \mathrm{mg}$ per $100 \mathrm{ml}$, and triglycerides $695 \mathrm{mg}$ per $100 \mathrm{ml}$. The alkaline phosphatase was $10 \mathrm{King}-\mathrm{Arm}-$ strong $\mathrm{U}$, thymol turbidity $0.5 \mathrm{U}$, bilirubin $0.1 \mathrm{mg}$ per $100 \mathrm{ml}$, and serum glutamic oxaloacetic transaminase 34 $\mathrm{U}$. The blood urea nitrogen was $12 \mathrm{mg}$ per $100 \mathrm{ml}$, and the total protein was $7.2 \mathrm{~g}$ per $100 \mathrm{ml}$ with $2.9 \mathrm{~g}$ of albumin and $4.3 \mathrm{~g}$ of globulin. An oral glucose tolerance test gave the following results : fasting, $27 \mathrm{mg}$ per $100 \mathrm{ml} ; 30$ minutes, $106 \mathrm{mg}$ per $100 \mathrm{ml} ; 1$ hour, $274 \mathrm{mg}$ per $100 \mathrm{ml}$; 2 hours, $242 \mathrm{mg}$ per $100 \mathrm{ml}$; 3 hours, $153 \mathrm{mg}$ per $100 \mathrm{ml}$; 4 hours, $74 \mathrm{mg}$ per $100 \mathrm{ml}$; and 5 hours, $29 \mathrm{mg}$ per 100 ml. After a fasting blood glucose of $25 \mathrm{mg}$ per $100 \mathrm{ml}$, $0.2 \mathrm{ml}$ of $1: 1,000$ epinephrine was injected subcutaneously. Fifteen minutes later the blood glucose was $13 \mathrm{mg}$ per 100 $\mathrm{ml}, 30$ minutes later it was $10 \mathrm{mg}$ per $100 \mathrm{ml}$, and $45 \mathrm{~min}$ utes later it was $9 \mathrm{mg}$ per $100 \mathrm{ml}$.

Liver and intestinal mucosa biopsies were obtained at surgery. The glycogen content of the liver was $8.6 \%$ based on wet weight of tissue. True glucose-6-phosphatase was absent from the liver, but the phosphorylase and debranching enzyme activities were normal (Table I).

\section{Acknowledgments}

The authors are indebted to Drs. Albert DeStefano, Wilmeding, $\mathrm{Pa}$, and Ramiro Estrada, San Antonio, Texas, for referring S.T. and D.R., respectively. We gratefully acknowledge the assistance of Drs. Lee Hershenson and Richard Wechsler, who performed the intestinal biopsies, and Dr. William Kiesewetter, who did the open hepatic and intestinal biopsies. Margaret McMennamin, Adrienne Remer, and Constance Boyle provided excellent technical assistance.

\section{References}

1. Williams, H. E., P. L. Johnson, L. F. Fenster, L. Laster, and J. B. Field. Intestinal glucose-6-phosphatase in control subjects and relatives of a patient with glycogen storage disease. Metabolism 1963, 12, 235.

2. Öckerman, P. A. Glucose-6-phosphatase in human jejunal mucosa. Lack of activity in glycogenosis of Cori's type 1. Clin. chim. Acta 1964, 9, 151.

3. Cori, G. T., and C. F. Cori. Glucose-6-phosphatase of the liver in glycogen storage disease. J. biol. Chem. 1952, 199, 661.

4. Sokal, J. E., C. U. Lowe, E. J. Sarcione, L. L. Mosovich, and B. H. Doray. Studies of glycogen metabolism in liver glycogen disease (Von Gierke's disease): six cases with similar metabolic abnormalities and responses to glucagon. J. clin. Invest. 1961, 40, 364.

5. Williams, H. E., and J. B. Field. Further studies on leukocyte phosphorylase in glycogen storage disease. Metabolism 1963, 12, 464.

6. Swanson, M. A. Phosphatases of liver. I. Glucose6-phosphatase. J. biol. Chem. 1950, 184, 647.

7. Sutherland, E. W. Polysaccharide phosphorylase, liver in Methods of Enzymology, S. P. Colowick and N. O. Kaplan, Eds. New York, Academic Press, 1955, vol. 1, pp. 215-222.

8. Hers, H. G. Etudes enzymatiques sur fragments hepatiques; application à la classification des glycogenosis. Rev. int. Hepat. 1959, 9, 35.

9. Williams, H. E., and J. B. Field. Low leukocyte phosphorylase in hepatic phosphorylase-deficient glycogen storage disease. J. clin. Invest. 1961, 40, 1841.

10. Williams, H. E., E. M. Kendig, and J. B. Field. Leukocyte debranching enzyme in glycogen storage disease. J. clin. Invest. 1963, 42, 656.

11. Carroll, N. V., R. W. Longley, and J. H. Roe. The determination of glycogen in liver and muscle by use of anthrone reagent. J. biol. Chem. 1956, 220, 583.

12. Lowry, O. H., N. J. Rosebrough, A. L. Farr, and R. J. Randall. Protein measurement with the Folin phenol reagent. J. biol. Chem. 1951, 193, 265.

13. Hass, L. F., and W. L. Byrne. The mechanism of glucose-6-phosphatase. J. Amer. chem. Soc. 1960, $82,947$.

14. Lea, M. A., and D. G. Walker. The metabolism of glucose-6-phosphate in developing mammalian tissues. Biochem. J. 1964, 91, 417.

15. Chiquoine, A. D. Further studies on the histochemistry of glucose-6-phosphatase. J. Histochem. Cytochem. 1955, 3, 471.

16. Hülsmann, W. C., T. L. Oei, and S. Van Creveld. Phosphorylase activity in leukocytes from patients with glycogen-storage disease. Lancet 1961, 2, 581 . 